\title{
RUSSIA AND THE SERBS (SERBIA) FROM THE EASTERN QUESTION TO CONTEMPORARY RELATIONS
}

\author{
Dragan Petrović, Ph.D. ${ }^{1}$
}

\begin{abstract}
Tsarist Russia defined its policy towards the Balkans, including Serbian territories, mostly within the framework of the Eastern Question. The fall and collapse of the Ottoman Empire after 1683, until the end of the First World War, meant the liberation and unification of the conquered Christian, mostly Orthodox peoples of the Balkan Peninsula and, at the same time, increased the influence of Russia, the Habsburg Monarchy and some other European powers. Russia's advantage within the Eastern Question was its cultural closeness with the Orthodox, especially Slavic peoples of the Balkans, and the joint centuries-long cooperation in the fight against the Ottoman Empire, which helped the liberation and unification of the Serbian and Yugoslav peoples. In the epoch of the existence of the USSR, that role became more complicated during the twentieth century because of the ideological issues, world wars, and then the relations between the superpowers and the two opposing blocs. After the disappearance of the USSR and the SFR Yugoslavia, modern Russia has renewed its cooperation and influence in the Balkans on new foundations. In the foreground is the energy policy of Russia, then the economics, but also the cultural and historical closeness. The gradual process of transforming the world order towards multipolarism and the military neutrality of Serbia (both $\mathrm{BiH}$ and the Republic of Srpska) also represent a connecting factor. Serbia's foreign policy concept of cooperation with several world centers of power (EU, Russia, USA, and China) also affects
\end{abstract}

\footnotetext{
${ }^{1}$ The author is a scientific advisor at the Institute of International Politics and Economics, Belgrade. E-mail: dragan.petrović@diplomacy.bg.ac.rs.

The paper was created within the project "Serbia and Challenges in International Relations in 2020", which is financed by the Ministry of Education, Science and Technological Development of the Republic of Serbia, and implemented by the Institute of International Politics and Economics in 2020.
} 
the deepening of cooperation with Russia. An important issue is Russia's support for Serbian interests regarding the problem of Kosovo and Metohija and the position of the Republic of Srpska.

Keywords: Eastern Question, Russian Federation, Serbia, Kosovo and Metohija, historical and cultural closeness, energy policy.

\section{The eastern question and Russian-Serbian relations}

Russia's attitude towards the Balkans, including the Serbian territories, developed gradually in the modern era, after the period when the Russian territories were freeing themselves from Mongol-Tatar pressure. While the Russian territories slowly emancipated and freed themselves from MongolTatar domination in the century after the Battle of Kulikovo, the Serbian territories were under the Ottoman occupation. The symbolic wedding of the Byzantine princess from the royal family Palaiologus (Sofia) with the Grand Duke Ivan III gave Moscow a symbolic legacy of being the "Third Rome" and the heir of the Roman Empire. Also, the cultural closeness with the Byzantine heritage gave an additional patronizing relationship and closeness to Russia as an empire in relation to the Orthodox Christian peoples of the Balkans. The Serbs as Orthodox Slavs certainly had a special significance here. The territorial and state unification of the Russian territories during the following period was especially helped by the breaking up of the Golden Horde into several independent and semi-independent khanates. Thus, Ivan the Terrible occupied the Kazan (1552) and Astrakhan Khanate (1556) and placed the entire waterway of the Volga in the internal composition of the Russian state. This was followed by the conquest of the Urals and Western Siberia, and during the 17th century of Eastern Siberia, and expanding to the Pacific. When eastern Ukraine and Kiev united with Russia in 1654, a more serious rapprochement with the Balkans began.

In that direction, the geopolitical preconditions for Russia's rapprochement with the Balkans and the Serbian territories were created for several reasons. First, the tsarist Russia of the Romanovs was constituted as the leading Eurasian power, which covered a colossal space, approximately from the Baltic and the Black Sea (but still without direct access to these seas) to the Pacific in the east. However, this colossal, the most spacious empire in the world, did not have direct access to the Baltic and the Black Sea even then. Moreover, it aspired to unobstructed access to 
free and warm seas (like the Mediterranean). On the other hand, the enslaved Orthodox Christian, and especially the Slavic peoples of the Ottoman Empire in the Balkans and also in Asia Minor (Armenians and Greeks), saw their liberation in the resolution of the Eastern Question and through Russia's help. (Петрович, 2013, стр. 119-132, 120).

The Eastern Question represented a period of more than two centuries in which this hub was resolved. The defeat of Turkey near Vienna and the beginning of the unstoppable process of its withdrawal from Europe and the Balkans at the end of the 17th century (starting from 1683 with the Peace of Karlovac as a temporary determinant on that road) coincided with the coming to power of Peter the Great. From his epoch, direct addressing and connecting began, and therefore the cooperation with the Serbian factor in the Balkans in favor of further resolving the Eastern Question. The common interest of Russia and the Serbs was obvious, i.e., the liberation of the oppressed Christian-Orthodox peoples of the Balkans (including the Serbs) and the expulsion of the Ottoman occupier from these areas. Figuratively, during the entire period of the Eastern Question, the sublimation of this aspiration was the transformation of the Hagia Sophia in Constantinople into an Orthodox Christian cathedral again. The Serbs cooperated in resolving the Eastern Question with other Christian powers, primarily with the Habsburg Monarchy, the Venetian Republic, etc., but Russia increasingly won their trust due to Slavism, Orthodoxy, and the long history of joint struggle against the Ottoman Empire. When Eastern Ukraine and Kiev joined Russia under Ataman Khmelnytsky in 1654, it started to approach the Balkans. In the period of Peter the Great, Russia had a colossal continental mass of Eurasia, from the Baltic Sea and the Sea of Azov to the Pacific. Therefore, its aspiration to extend to the coastal seas and, at the same time, to become an important factor in resolving the Eastern Question was an interconnected process. Thus, the aspiration of Orthodox Christians to free themselves through the Eastern Question from the Ottoman Empire and the interests of Russia coincided (Успенски, 2013); Поповић, 2003; Нарочницкого, 2003).

On the one hand, Russia's interest was to reach the warm seas with new territorial expansions, but also to support the creation and expansion of the newly created Orthodox peoples' (and often Slavic) states in the Balkans and the Middle East, which Russia considered as akin and cultural-civilizational close states. During the 18th century, Russia became more and more geographically "closer" to the Balkans because it took control of the north and east Black Sea 
coasts as a result of a series of victories in the wars with the Ottoman Empire, and on the other hand, by the expansions at the expense of Poland.

The attractiveness of Russia compared to other Christian powers in resolving the Eastern Question was significantly bigger, especially for the Serbs, which was shown by the fact that in the 18th century, on several occasions, there were migrations from the area under the Habsburg monarchy to the eastern Ukrainian steppes and other areas of then southern Russia (Рудјаков, 1995). The cooperation between the Serbian Orthodox Church and Russia and the Russian Orthodox Church has been especially intense since the Middle Ages. In that direction, the historian Dejan Tanic speaks about the phase of the spiritual-ideological aspect which lasted until the end of the 16th century, then the political-diplomatic phase which lasted until the beginning of the 18th century, and the cultural-educational phase which lasted until Vuk's reforms (Танић, 2013, стр. 7-9).

From the final decades of the 18th century, therefore, Russia's influence in the Balkans and the Serbian territories increased due to the occupation of the entire Black Sea north coast, the conquest of Bessarabia, and reaching of the Danube's estuary at the beginning of the 19th century. On the other hand, after the peace in Iasi in 1791, the Belgrade Pashaluk returned to the Ottoman Empire after the occupation of the Habsburg monarchy, but now it has gained certain autonomy. During the First Serbian Uprising, Russia and insurgent Serbia were allies and Russian troops came to Serbia in a joint victorious fight against the Ottoman Empire. When Napoleon left for Russia in 1812, Alexander I was forced to sign the Peace Treaty of Bucharest with Turkey. However, in point eight, Serbia was guaranteed broad autonomy. It was an important international treaty, which helped Milos Obrenovic not to re-enter the armed conflict with the Ottoman Porte after 1815. Using the achievements of the Vienna Congress and the fact that Russia was one of the leading victors over Napoleon (the Great Alliance) enabled Milos a great influence on the organization of Europe. After that, the Principality of Serbia, although it remained out of the war conflict with the Ottoman Empire, gained several expansions and confirmation of its growing independence. ${ }^{2}$ Russia's victory in the war with Turkey and the Treaty of Edirne brought

\footnotetext{
${ }^{2}$ Although neutral in that war, with Milos's diplomacy, Serbia achieved that the Bosnian viziers and the Skadar pashas did not arrive in time to help the sultan in key battles with the Russian army.
} 
Milos's Serbia the Hatisheriff from 1830, confirming the previous great autonomy to the level of internal independence, and with Hatisheriff from 1833 , Serbia gained the expansion by six nahiyes.

\section{The importance of Tsarist Russia in international relations in the new age period, and Russian-Serbian relations}

In modern history, Russia has practically continuously increased its significance and influence, including during the epoch of the Eastern Question. Territorial expansion in Eurasia, an increase of the number of inhabitants, military and economic power, participation in various victorious coalitions in European affairs, made Russia a great power. During the 18th and the beginning of the 19th century, it geographically approached the Balkans, occupying the entire northern and eastern shores of the Black Sea, and finally the Danube estuary. That process was not absolutely straightforward. This was the case after the defeat in the Crimean War, where the Paris Peace Agreement of 1856 was not particularly exemplary towards Russian interests, but it was still a step back from the previous positions. Half a century after that, the defeat in the war with Japan in the Far East and the beginning of the internal revolution were also an obvious step back. At the internal level, modernization, the liberation of serfs, the process of urbanization and development, which had its backlogs and contradictions that will remain evident until the Great War, continued. Taken as a whole, with some setbacks, Russia in the entire modern history and the process of resolving the Eastern Question was advancing and developing until the Great War of 1914. That Great War, especially the October Revolution, represented a watershed, and a completely new position of Soviet Russia (USSR) in relation to the previous epoch.

The characteristics of Russian-Serbian relations during the Eastern Question, until the beginning of the First Serbian Uprising, were as follows: 1) a constant deepening of ties, as a consequence of the coincidence of interests in the direction of the fight against the Ottoman Empire, and cultural and national kinship; 2) Russia's constant territorial approach to the Balkans and the Serbian territories, especially during the second half of the 18th century. However, in the physical sense, there was no contact between the Russian Army and the Serbian people in the Balkans, except 
for the assistance provided to Montenegro by the navy and in other ways. There was also the migration of the Serbs to south Russia, primarily today's area of eastern Ukraine. Within the attitude of the Western powers towards the Serbian issue, the attitude they had towards Russia was also important. Great Britain (and later such a course was largely accepted by the United States during the twentieth century) saw Russia as the most important planetary adversary within its geopolitical interests. Great Britain viewed the Serbian factor mostly negatively since it was close to Russia. In principle, France took a far more favorable attitude towards both Russia and the Serbian issue. Germany had a changing attitude towards Russia until the conclusion of the Franco-Russian alliance in 1891. Before German unification, the most important German states also had a changing attitude towards Russia. However, after Bismarck came down from power, Germany tightened its policy towards Russia. This coincided with the worsening of the policy of the Habsburg monarchy towards the Serbs and the binding of Vienna to the policy of Berlin.

The characteristics of Russian-Serbian relations from the First Serbian Uprising until the end of the First World War were as follows: 1) more direct cooperation, the Russian army physically present in the First Serbian Uprising, and then through volunteers in the Serbian-Turkish wars of 1876 and 1877-78; 2) in the later war (1877-78), the Russian army fought against Turkey in the Balkans (in present-day Bulgaria). The situation was similar in the First World War. During the 19th and the beginning of the 20th century, Russia's relations with Serbia and Montenegro deepened in the military, political, spiritual, cultural, and economic domains. This did not apply evenly to all periods, so there was a cooling of relations during the reign of the King of Milan when official Belgrade pursued an Austrophile policy. Montenegro relied on Russia practically all the time of its existence in the modern period, although, at the same time, it established relations and cooperation with some other powers. Since the formation of the FrancoRussian alliance in the early 1990s, Montenegro has been oriented in that direction (besides, it maintained friendly relations with Italy, and even with Austro-Hungary), and Serbia was definitely tied in that direction after the May coup in 1903. Russia finally entered the Great War precisely on the issue of the Austro-Hungarian attack on Serbia. Of course, the motives for the great European conflict were more complex and embedded in the long-term contradictions between the two opposing military-political blocs of the 
Entente and the Central Powers. Russia's entry into conflict with the Central Powers over Serbia (Austria-Hungary wanted its local war with Serbia with the support of Germany) while the Russian army and economy were not yet ready for a major conflict, recovering from the internal revolution and war with Japan 1904-1905, represented great help to the Serbs and the significant support in the just ended era of resolving the Eastern Question. The victories of Serbia and Montenegro in the Balkan wars marked the end of the era of the Eastern Question for the Serbs, but a great conflict was imposed on them by the Central Powers in 1914.

\section{Russian-Serbian relations after 1918}

It was the paradox that, after the October Revolution, Russia, which was one of the pillars of the Entente and made great sacrifices until the beginning of 1918 for its final success, after the victory of the Bolsheviks, became a country opposed to the victorious Versailles system for ideological reasons. In that direction, both Serbian and Yugoslav unification remained without Russia's support in the Versailles Peace Treaty. This was one of the important reasons why a great Serbian united state could not be formed in Versailles. This issue was not supported by Western powers, but also from France. Instead, a Yugoslav state was created. In the interwar period, the relations of Soviet Russia with the Versailles system in Europe were even hostile in the first phase (and thus with the Kingdom of Yugoslavia, they were far from the previous centuries-old Serbian-Russian friendly cooperation). The turning point was the arrival of the Nazis to power, the entry of the USSR into the League of Nations and the Franco-Soviet Pact, which had only a partial result in the existing balance of power in Europe (Петровић, 2019, стр. 115-118). The USSR was in a kind of isolation during a significant part of the interwar period in relation to the Versailles system in Europe. All this was reflected in the Soviet-Yugoslav relations. Due to ideological differences, blood ties of the Karadjordjevic dynasty with the executed Romanov dynasty, but also due to the opposition that the Bolshevik regime in Moscow had to the Versailles system and Yugoslavia as its link, the differences between the authorities in the Kingdom of Yugoslavia and the USSR were very pronounced. Even in the period after the entry of the USSR into the League of Nations and Moscow's rapprochement with Paris 
and Prague, these relations slowly warmed up, which was largely a consequence of the concept of Prince Pavle and Milan Stojadinović. Over time, there came to the warming and rapprochement, while official relations were not established until June 1940, but then started to deepen. ${ }^{3}$

The Second World War additionally brought together the Russian and Serbian peoples, who were fighting on the same side. After the war, although both countries were socialist, there were differences. The USSR was a world superpower and the leader of the Eastern Bloc. It regained the territories it partially lost after the foreign intervention and the civil war on the western outskirts of the country. Moreover, it possessed nuclear weapons and a permanent seat on the Security Council with the right of veto.

During the twentieth century, the Serbian and Russian people, that is, the states in which they lived (USSR and Yugoslavia), had specific and unequal relations in the complex ideological and then the Cold War opposites of Europe and the world. The Kingdom of Yugoslavia was even among the last states in the interwar period to establish diplomatic relations with the USSR, and relations between Tito's Yugoslavia and the USSR were changeable, although close in principle.

After the disintegration of the complex states in which they were in 1992, Russia and Serbia (FRY) came out of that process evidently severely mutilated (to this the mostly unfounded accusations that they had the role of hegemon in the USSR and the SFRY should be added), leaving outside their borders significant parts of their own people. After the difficult 1990s, which were hard for both countries, it seemed that, in the past two decades, mutual relations had been rising constantly and with even greater predispositions for future development.

With the fall of the Berlin Wall and the disappearance of the USSR, a (temporary) monopolar world order emerged with the dominance of the USA and NATO. Within that emerging monopolar world order, the Yugoslav crisis developed, which ended during the 1990s to the detriment of the Serbian factor. During that period, although after several decades spent in a complex state, independent states emerged. The Serbs (the Federal Republic

\footnotetext{
${ }^{3}$ More details in Dragan Petrovic's books: Краљевина Срба, Хрвата и Словенаца и Совјетска Русија (СССР), Краљевина Југославија и СССР 1929-1935, Краљевина Југославија - СССР 1935-1941 (Петровић, 2018; Петровић, 2019; Петровић, 2017).
} 
of Yugoslavia) and Russia could not develop adequate cooperation in such circumstances. Russia was not in a position to help resolve the Yugoslav crisis equally and fairly.

\section{Russian-Serbian relations after 2000}

However, since Vladimir Putin came to power, Russia has gradually and significantly strengthened. In these last two decades, relations between Serbia (FRY until 2006, i.e., Serbia and Montenegro) and the Republic of Srpska, and Russia were good and multidimensional. During this period, Russian-Serbian relations were developing on the basis of traditional closeness, but also in the context of geopolitical and state interests of both sides. Regarding the issue of Kosovo and Metohija, Russia supported Serbia. Russia is interested in preserving the territorial integrity of Serbia for several reasons. It is a principled position on the immutability of borders by unilateral pressures. Secondly, in this epoch of aggressive policy of the USA and NATO, first of all, the status quo in international relations suits Russia better. Next, the Serbian factor is close and traditionally friendly, and stable Serbia is in Russia's interest. Moreover, the precedents in the former Yugoslavia could serve as a laboratory and a precedent in a number of other neuralgic points, including the post-Soviet space where Russia has first-rate strategic interests. Through its support to Serbia on the issue of Kosovo and Metohija, Russia has an additional factor of influence in the Balkans, which confirms its status of great power.

Serbian political scientist Dragan Simeunović points out that "Vladimir Putin's rise as a statesman and international successes as the President of Russia, the renewal of the Russian state and military power, and his determination to question the fate of Serbia, has made visible Russia's popularity in the eyes of Serbs again, and the myth of the fraternal and protective position of Russia has gained new strength" (Симеуновић, 2018, стр. 318). The re-strengthening of Russia in the era of Vladimir Putin strengthened the traditional faith of the Serbian population in Russia.

Political scientist Leonas Tolvaishis believes that after the withdrawal of its peacekeeping contingent from the UN forces in Kosovo and Metohija in 2003, Russia primarily concentrated the concept of "soft power" on the Serbian territories. It is a range of cooperation in the field of politics, defense, 
economy, and cultural identity. In the field of politics, it is primarily Russia's support for the territorial integrity of Serbia regarding Kosovo and Metohija. It is important for Russia that in 2007 Serbia declared military neutrality as a state concept. It is also important that Serbia became an observer in the CSTO. In 2017, Serbia bought military equipment from Russia, primarily six MiG-29 aircraft, thirty T-72 tanks, armored personnel carriers, and other (Толвайшисю, 2019, стр. 99-102).

In economic terms, during the last two decades, in parallel with the economic and social rise of Russia, its economic cooperation with the Balkans, including the Serbian territories, has intensified. At the beginning of the second decade of the 21st century, the foreign trade cooperation between Serbia and the Russian Federation was around 3 billion euros ${ }^{4}$, and in the following years, it will experience smaller fluctuations. The coverage of Serbian exports to Russia in relation to imports increased from about one-seventh of the total bilateral exchange in 2008 to one-third in 2018. If we look at the bilateral trade exchange between the two countries in recent years, we can see that from 2013 to 2018, this balance was quite stable, i.e., that the coverage of imports by exports was about 40 to $60 \%$. Exports were approximately one billion dollars and imports about two billion dollars (Привредна комора Србије, 2019).

Russia is generally in the fourth place of Serbia's foreign trade partners, behind Germany, Italy, and China. The structure of Serbian exports is dominated by food products, clothing, pneumatic products, etc. In the structure of imports, energy, oil and gas are in the first place, accounting for over $60 \%$ (Петровић и Јокић, 2015, стр. 104-110). It is clear that such a high structure of energy imports, called an inelastic type of product in economic science (for which it is difficult to find a substitute), conditions the negative bilateral foreign trade balance of the two countries to the detriment of Serbia. Therefore, it is no wonder that Russia has had a positive foreign trade balance with the world for years, often twice as much

\footnotetext{
${ }^{4}$ The record in the foreign trade of the two countries was achieved back in 2008 when it amounted to $\$ 4$ billion. For example, in 2019 , $\$ 3.6$ billion was reached. However, compared to 2008, Serbian exports in the foreign trade of the two countries are extremely advanced, so in 2008 it amounted to only $\$ 500$ million (one-eighth of the total bilateral exchange that year), and in 2019 as much as $\$ 1$ billion (close to $30 \%$ of bilateral trade) (Политика, 2013).
} 
nominally as imports because the dependence on imports of its energy sources is high (Привредна комора Србије, 2019).

There are as many as 895 active business entities on the territory of Serbia, whose majority owners are legal entities from the Russian Federation.

In the institutional sense of economic cooperation, the Free Trade Agreement signed in 2001 is important. It is one of the few that Russia has signed with some country, and it provides ample opportunities for successful bilateral cooperation. For almost two decades, this agreement has only been partially used in relation to the possibilities and the perspective of increasing cooperation. The Agreement of February 28, 2008, signed after the session of the expert working group of the Government of the Republic of Serbia and the Government of Moscow determined the basic directions for strengthening trade and economic cooperation. (Петровић, 2018, стр. 401-402). On the issue of military cooperation, the status of military neutrality of Serbia positively affects the maintenance of military cooperation with Russia as well. In 2014, Vladimir Putin attended the military parade of the Serbian Army in Belgrade, which was held for the first time in three decades (Восток, 2019).

Since 2014, Serbia has been regularly participating in the Slavic Brotherhood Military Exercise together with Russia and Belarus. During 2019, Serbia held four military exercises with Russia (Center for EuroAtlantic Studies, 2019). In recent years, Serbia has stepped up its arms purchases from Russia, and since 2013, Serbia has been granted observer status within the Collective Security Treaty Organization (Организация Договора о коллективной безопасности, 2020). ${ }^{5}$

For Serbia (and the Republic of Srpska), the integration processes and international organizations in which the Russian Federation is located are an additional factor in relations with Russia. It is the whole spectrum, starting from the post-Soviet space, where the Eurasian Union dominates in the economic sense, then the Commonwealth of Independent States, and finally, in the security sense, the Organization for Collective Security and Cooperation. Then follows the Shanghai Cooperation Organization and the

\footnotetext{
${ }^{5}$ Within its observer status, Serbia monitors the activities of the CSTO continuously, thus, among other things, the National Assembly of Serbia has been an observer of the work of the CSTO Parliamentary Assembly for years.
} 
BRICS, which have a wider (Eurasian, i.e., the world) significance. Serbia has the status of an observer within the SCO. Serbia is a status-neutral state in military terms, so cooperation with the CSTO (where it is an observer), and in the future with the SCO, may suit it to strengthen its neutral status. When it comes to the Eurasian Union, first of all, the CIS and especially the BRICS, Serbia can strengthen its economic cooperation. For example, the BRICS Development Bank also provides loans to third countries without conditioning the application of the economic concept or even political issues.

If we consider the importance of Serbia in the official strategic documents of the Russian Federation in the last twenty years, we can notice the following. The 2000 document, as the first strategic concept since President Vladimir Putin came to power, cites the Russian Federation's interest in the survival of the Federal Republic of Yugoslavia, and the issue of Kosovo and Metohija" as the most important in the Balkans". Russia's direct interest was linked to the survival and the territorial integrity of the FRY because the alternative was the possibility of a "general Balkan conflict". The next strategic document of the Russian Federation from 2008 does not mention Serbia at all. The 2013 strategic document states the importance of the Balkans in Russia's transport and energy policy and provides a general guideline for supporting the territorial integrity of the Balkan states, including Serbia. It is similar in the 2016 document. Russian political scientists Bokerija and Pejic, on the other hand, point out that although in the official documents the strategy towards Serbia is not particularly elaborated and even mentioned in some of them, the importance of the Balkans and Russian-Serbian relations is evident. In the light of the transport of Russian energy, the fact that Serbia territorial integrity is endangered on the issue of Kosovo and Metohija, this insistence on territorial integrity is of special importance. The high frequency of mutual meetings at the top in recent years is pointed out. The record was in 2017 when as many as six such meetings were organized. In 2013, the Declaration on Strategic Partnership was signed between Serbia and Russia, where, in addition to economic cooperation, the possibility of military cooperation was also mentioned. The issue of Kosovo and Metohija, i.e., the territorial integrity of Serbia, was mentioned as one of the important factors of the Russian side in mutual summits, but also in the statements of the Russian side. After the introduction of sanctions regarding the Ukrainian crisis by a number of Western countries, Serbia did not participate in it (Бокерия и Пеич, 2018. стр. 93-96). 
For official Russia, the issue of Kosovo and Metohija is primarily a question of the territorial status and integrity of Serbia. Therefore, Russia refers to Resolution 1244, which considers Kosovo and Metohija as an integral part of the FR Yugoslavia, i.e., Serbia. Some Russian political scientists, such as Sergei Vyacheslavovich Moshkin, believe that after the annexation of Crimea to Russia and the separation of Abkhazia and South Ossetia from Georgia, as well as some other controversial situations in the post-Soviet space, the territorial integrity is not considered so decisively final category in international relations. (Вјачеславович, 2018, стр. 164). An Austrian expert on international law Benedikt Harzl thinks similarly. He assumes that if Kosovo were alienated from Serbia under any explanation, then a similar status issue would be raised for the post-Soviet space and, for example, the issues of Abkhazia, South Ossetia, and others (Гарцлъ, 2018, стр. 105).

\section{Perspectives of Russian-Serbian cooperation}

The modern world is in the process of growing from a monopolar, where it was after the "fall of the Berlin Wall" towards a multipolar one. In addition to the United States, other world powers, primarily China, Russia, and even India, Germany, France, Britain, Japan, and Brazil, have a significant influence in the multipolar world order. The collapse of the neoliberal economic and social concept in recent years has hit the United States and the Anglo-Saxon world the hardest. The planetary process of the easy transition of the center of the world economy from the North Atlantic to the Pacific region is also underway (with an emphasis on China, but also other countries and areas of the Far East and the west coast of Anglo-America). In the new circumstances, the BRICS countries, in particular, will stand out as "continent countries" with large territories, large populations, and natural resources. In that direction, the Russian Federation gained additional importance. Its energy sources and other strategic resources (metal and non-metal ores, clean drinking water, forests, arable land) will gain in importance. When it comes to oil and gas, for example, the neighboring macro-regions (China, EU countries, Japan, India, etc.) are increasingly deficient in these resources, and Russia will be able to export in respectable quantities in the coming decades. It is clear from all this that Serbia's strategic interest is to maintain and 
expand the closest possible cooperation with Russia, with which it shares ethnic and cultural closeness and historical alliance.

In the strategic sense, this cooperation consists of political and security ties because the Russian Federation represents an important pole of influence in international relations, including the Balkan Peninsula. This especially refers to the issue of Kosovo and Metohija and Russia's support for Serbia. Russia is also acting positively on the issue of the position of the Republic of Srpska and the respect for the Dayton Accords, as one of the signatories of this international peace agreement which regulates peace in Bosnia and Herzegovina. Integrations in the post-Soviet space and international organizations in which Russia participates (SCO, CSTO, BRICS, Eurasian Union, CIS) are also important for the interests of Serbia, which has opted for a neutral position in terms of security. In the economic sense, regardless of the proclaimed policy towards the EU, Serbia is interested in economic cooperation with Russia and integrations in which it has an important role. After all, Serbia has a special status in trade cooperation with Russia, and, among other things, the status of an observer in relation to the CSTO. Russia supports the change of Djukanovic's regime and concept in Montenegro, which was achieved in the parliamentary elections on August 30, 2020. These changes are in the Serbian interest for several reasons, primarily in improving the strategic relations between Serbia and Montenegro. Cooperation in the field of culture, tourism, transport also offers great potential.

In the economic domain, Serbia is directed to import primarily Russian energy. On the other hand, in the structure of exports, special potential represents the food products and cooperation with Russia in joint production and the agreed placement for Russian areas of deficient agricultural products and the introduction of high technologies (Буквич, Пайович, Петрович, 2016).

\section{References}

Centar za evroatlantske studije. (2019). Srpska vojna saradnja u 2019: 13 vežbi sa NATO i četiri sa Rusijom. Link: https://www.ceas-serbia.org/sr/ preuzeto/8513-srpska-vojna-saradnja-u-2019-13-vezbi-sa-nato-icetiri-sa-rusijom, 22/08/2020. 
Бокерия С. А., Пеич И. (2018). Россия и Сербия: Пути взаймодеивстия, Россия и мир в XXI веке, Москва, стр. 92-100. Линк: https://cyber leninka.ru/article/n/rossiya-i-serbiya-puti-vzaimodeystviya.

Буквич М. Б. Р., Пайович И. С., Петрович Д. Р. (2016). „Растениеводство в Волго-Вятском регионе и в Придунавъе Сербии: Сравнителный анализ и возможности сотрудничества“, Вестник НГИЭИ, Нижегородски государствени инженерно-экономический университет НГИЭИ, Ежемесячныи научный журнал, октябар, стр. 119-134.

Вјачеславович М. С. (2018). „Косовский прецедент, в дискурсе заявлений росссийского руководства, Парадигмы и процессы", Москва, стр. 159-168. Линк: https://cyberleninka.ru/article/n/ kosovskiy-pretsedent-v-diskurse-zayavleniy-rossiyskogo-rukovodstva/ viewer.

Восток. (2019). Руско-српска војна сарадња: Како Русија опрема и увежбава војску Србије. Линк: https://www.vostok.rs/index.php? option=btg_novosti\&catnovosti=8\&idnovost=122527\&Rusko-srpskavojna-saradnja:-Kako-Rusija-oprema-i-uvezbava-Vojsku-Srbije, 20/08/2020.

Гарцлъ Б. (2018). „Открытие Ящика пандоры, или как право на самоопределиние разжигает обманчивые страсти: некоторые международно-правовые аспекты независимости Косова“, Москва, стр. 93-116. Линк: https://cyberleninka.ru/article/n/otkrytie-yaschika -pandory-ili-kak-pravo-na samoopredelenie-razzhigaet-obmanchivyestrasti-nekotorye-mezhdunarodno-pravovye-aspekty/viewer.

Нарочницкая Н. А. (2003). Россия и русские в мировой истории. Москва: Междунар. Отношения.

Нарочницкого А. Л. (2003). Нарочницкая Н. А. Россия и русские в мировой истории. Москва: Междунар.

Организация Договора о коллективной безопасности. (2020). Генеральный секретарь ОДКБ Станислав Зась принял участие в заседании Совета Парламентской Ассамблеи Организации Договора о коллективной безопасности и проинформировал об обстановке в зоне ответственности ОДКБ. Линк: https://odkbcsto.org/news/news_odkb/generalnyy-sekretar-odkb-stanislav-zas- 
prinyal-uchastie-v-zasedanii-soveta-parlamentskoy-assambleio/?sphrase_id=65512, 28/08/2020.

Петровић Д. (2017). Краљевина Југославија - СССР 1935-1941. Београд: Институт за међународну политику и привреду.

Петровић Д. (2018). Економска сарадња Србије и Русије у геополитичком окружењу. Београд: Институт за међународну политику и привреду.

Петровић Д. (2018). Краљевина Срба, Хрвата и Словенаца и Совјетска Русија (СССР) 1918-1929. Београд: Институт за међународну политику и привреду.

Петровић Д. (2019). „Економска сарадња Србије и Русије у геополитичком окружењу, Увод у право Русије, Србија и Русија кроз векове, Правни факултет, Универзитета Београд, Службени гласник, Београд, стр. 399-420.

Петровић Д. (2019). Краљевина Југославија и СССР 1929-1935. Београд: Институт за међународну политику и привреду, Београд.

Петровић Д., Јокић А. (2015). Енергетска политика Русије. Београд: Институт за међународну политику и привреду.

Петрович Д. (2013). „Россия и Балканы - историческое наследие и современные отношения", Выстраивая добрососедство, Россия на пространствах Европы, Ассоциация Европейских исследований, Институт Европы, Российской Академии наук, Москва, стр. 119-132. Петрович Д. (2013). „Россия и Балканы - историческое наследие и современные отношения", Выстраивая добрососедство, Россия на пространствах Европы, Ассоциация Европейских исследований, Институт Европы, Российской Академии наук, Москва.

Политика. (2019). Spoljno-trgovinska razmena sa Rusijom 3,6 milijardi dolara. Link: http://www.politika.rs/sr/clanak/424393/Spoljnotrgovinska-razmena-sa-Rusijom-3-6-milijardi-dolara, 25/08/2020.

Поповић В. (2007). Источно питање. Београд: Никола Пашић.

Привредна комора Србије. (2019). Спољнотрговинска размена Републике Србије и Руске Федерације. Линк: https://api.pks.rs/ storage/assets/Kratka\%20informacija\%20Ruska\%20Federacija.pdf

Рудјаков П. (1995). Сеоба Срба у Русију у 18 веку. Београд: Службени лист СРЈ. 
Симеуновић Д. (2019). „Мит о Русији код Срба - настанак, развој и присутност у савремености", Увод у право Русије, Введение в право России, Србија и Русија кроз векове, Сербия и Роосия сквозъ века, Правни факултет, Универзитета Београд, Службени гласник, Београд, стр. 307-322.

Танић Д. (2013). Руско царство и Српска православна црква 1557-1766. Ниш: Друштво српско-руског пријатељства, Наисус.

Толвайшисю Л. (2019). „Сербско-россиское сотрудничество как ресурс внешней политики российской федерации“, Вестник Московского университета, Политические науки, Серия 12, н. 2, стр. 97-104.

Успенски Ф. (2013). Источно питање. Логос, Београд. 